\title{
TIME REFERENCE IN RUSSIAN CAUSATIVE CONSTRUCTIONS
}

\author{
ALEXANDER LETUCHIY \\ National Research University Higher School of Economics, Moscow
}

\section{[1] INTRODUCTION}

Russian belongs to the class of languages that do not mark the causative meaning grammatically. In the typology proposed by Nichols et al. (2004), Slavic languages are included in the class of detransitivizing languages. In other words, valency increase is not grammatically marked in this language group, whereas different types of valency decrease have a regular grammatical expression (see Paducheva (2001), among others on anticausative marking in Russian). More precisely, all Slavic languages employ the polysemous reflexive / reciprocal / anticausative marker that can be reconstructed back to the Proto-Slavic reflexive pronoun (in Russian, this marker became the verbal suffix -sja), which fulfills numerous valency-decreasing functions.

However, in this paper I will consider the causative constructions in Russian. Like most detransitivizing languages, Russian has the means to express the causative meaning, though these means are lexical, and not grammatical (see Shibatani (1976), especially Comrie (1976), Shibatani \& Pardeshi (2002), Shibatani \& Pardeshi (2002) on grammatical means of expressing the causative meaning). For instance, there are numerous verbs with the causative meaning, such as zastavit' (perfective ${ }^{1}$ ) / zastavljat' (imperfective) 'make', vynudit' (pf) / vynuždat' (ipf) 'force', pozvolit' (pf) / pozvoljat' (ipf) 'let, allow', razrešit' (pf) / razrešat' (ipf) 'permit' and so on. These lexical items do not show any clear sign of grammaticalization as understood, for instance, by Lehmann (1982) or Bybee et al. (1993). For example, they do not become morphologically dependent and do not lose any morphosyntactic features of independent verbs, e.g., they have the full paradigm of tense, person, gender, and number forms. However, as I will show, some semantic features distinguish constructions with causative verbs from the usual constructions with matrix predicates where the main verb is in a finite form and the embedded predicate is in the infinitive form.

[1] In what follows, I take into account only the simplest meanings of Russian perfective and imperfective verbs, namely, actual situation, taking place in the reference point, for imperfective, and finished situation for perfective. Other interpretations, such as the habitual interpretation for imperfective, are not taken into account, unless other is explicitly stated. 
In what follows, I examine the use of tense and aspect in constructions with the verbs zastavit' / zastavljat' 'make' and pozvolit' / pozvoljat' 'let, allow' (see Boguslavskaya (2005) where these and some other units are analyzed from the point of view of lexical semantics) ${ }^{2}$. I also include the verb delat' / sdelat 'make' in my analysis, though, as I will explain, this verb has special syntactic and semantic characteristics. It seems that the conclusions are valid for other causative verbs also, such as vynudit' 'force', but I do not consider them here.

Let me remind some terms that are necessary for the analysis of causative constructions. The object or situation which causes the occurrence of the situation coded with the base verb is called causer (for instance, the victory in example (3)). The object or situation which is forced or allowed to carry out the action or participate in the situation coded with the base verb (e.g., Sainz in (3)) is causee).

\section{Verb infinitive construction}

All causative verbs under analysis, except delat' / sdelat 'make', govern an infinitive construction. In Russian, there are many verb classes which can head an infinitive clause - either under the condition of co-reference of the subject of the embedded clause with the subject of the main clause or not. Let me briefly sketch the types of verbs which can form the verb + infinitive constructions - thus, they can embed another verb in the infinitive form. The list includes, among others, the following verb classes:

$\Rightarrow$ Verbs of wishing: xotet' 'want', želat' 'desire'

$\Rightarrow$ Verbs of verbal causation: prosit' 'ask', trebovat' 'demand'

$\Rightarrow$ Verbs of ability and possibility: moč' 'can', udat'sja 'manage'

$\Rightarrow$ Verbs of attitude: ljubit' 'love, like', ustat' 'be tired', nadoest' 'bother'

This list is, however, not homogenous. Most verb classes (verbs of wishing, ability, and most verbs of attitude) admit the infinitive construction only if the subject of the matrix clause is co-referent to the subject of the embedded clause.

However, some verbs (verbs of verbal causation, the verbs udat'sja 'manage' and nadoest' 'bother') do not require this type of co-reference. The verbs prosit' 'ask', udat'sja and nadoest' require that the subject of the embedded clause must be co-referent to the dative argument of the main clause, while in constructions with the verb trebovat' 'demand', the subject of the embedded clause usually has no co-referent argument in the main clause.

[2] The structure of event and aspectual properties of grammatical causatives is analyzed, for instance, by Ivanov \& Babicheva (2010). 
In what follows, I will compare the interpretations of tense / aspect forms of the main verb which are accessible in the causative constructions under analysis to the interpretations of other types of infinitive constructions. I will show that the semantic properties of the causative constructions differ from those of other infinitive constructions, which is an argument for the special status of causative constructions.

\section{[2] PRESENT TENSE OF THE MATRIX PREDICATE}

The present tense of the matrix predicate does not have any special features with most verb classes. For instance, in (1), with a verb of wishing, and in (2), with a verb of verbal causation, the present tense of the matrix predicate refers to the situation of, respectively, wishing, and the speech act:

$$
\begin{aligned}
& \text { Mam-a xoč-et, čtoby ja ej pozvoni-l- } \emptyset \text {. } \\
& \text { mother-SG.NOM want-PRS.3SG that I she.DAT call-PST-SG.M } \\
& \text { 'My mother wants me to call her.' }
\end{aligned}
$$

(2) Ja tebja proš-u bol'she tak ne dela-t'.

I you.ACC ask-PRS.1SG more so not do-INF

'I ask you not to do so anymore.'

The wish and the speech act take place, roughly speaking, in the moment of speech. However, neither (1) nor (2) bears any information concerning the question of when the embedded situation takes place - for instance, in (1), when I will call mother. The tensed form denotes only the time when the desire or the request takes place. This is not the case in causative constructions.

\section{[2.1] (S)delat'}

First, let me examine the case of the verb (s)delat' 'make'. The construction which we are interested in contains the imperfective variant of this verb delat' (with the perfective variant, the interpretation seems to be as with other verbs taking sentential arguments).

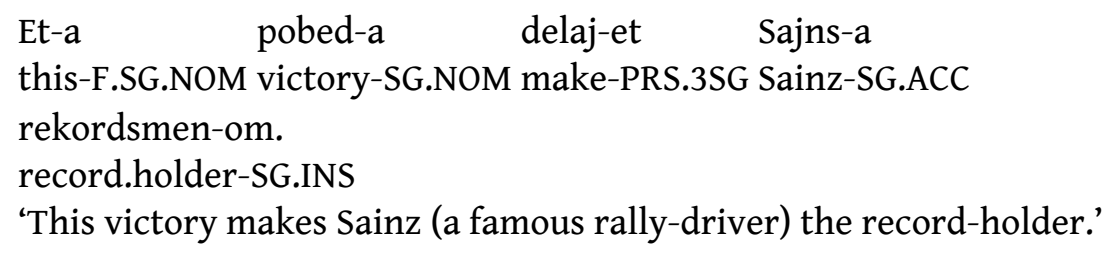


The verb (s)delat' 'make' does not form a polypredicative construction. Its object is an NP in the instrumental case denoting the resulting property of the causee which it gets under the affect of the causer. ${ }^{3}$

The sentence (3), found in Google, is not uttered at the moment when Sainz becomes the record-holder. It is uttered at the moment when he is already the record-holder. Thus, the present tense of delat' does not refer to the time of causation. By contrast, it refers to the time when the resulting state of affairs ('Sainz is the record-holder') takes place.

An interesting issue is the type of interpretation of the present tense in examples like (3). It seems that the form delaet 'makes' in (3) can be said to have a special type of actual (progressive) interpretation, though referring to the moment when the situation 'to be a record-holder' takes place. However, the classification of meanings of temporal and aspectual form is outside the scope of the present paper. Note that the interpretation in (3) is only accessible when the causer is a situation, as it is in the case of (3), where the subject position is occupied by pobeda 'victory'. However, when the causer is an agent, this meaning is impossible: for instance, in (3), where the causer is an agent novyj trener 'new coach', the present tense will have another meaning: ${ }^{4}$

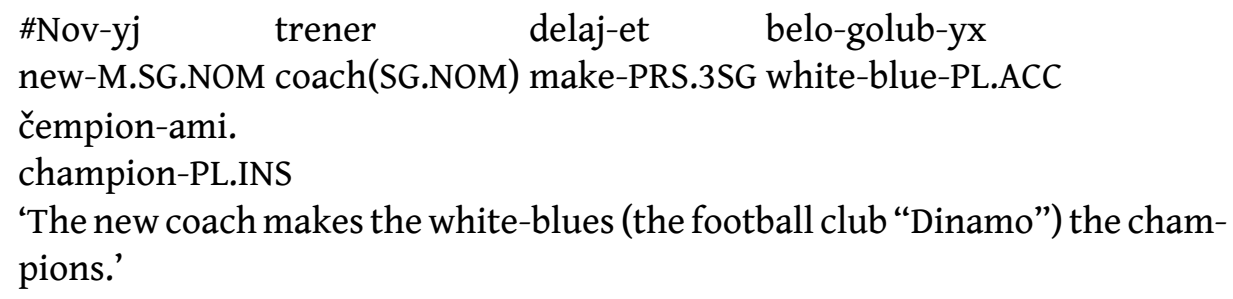

In this case the present tense can only refer to the time of causation - in other words, at the moment of speech, "Dinamo" is not the champion, and the new coach is in the process of making them champions. Let me now examine other causative verbs, zastavit' and pozvolit'. They behave syntactically as canonical lexical causatives, forming a polypredicative construction.

\section{[2.2] Zastavit' and pozvolit'}

Zastavit' 'make' and pozvolit' 'let' are the main causative verbs in Russian. For instance, in the Russian National Corpus, they occur more often than any of the other causative verbs. One more remark about these two verbs is called for: both of

[3] Note that sdelat' is not a canonical causative verb in terms of Shibatani (1976) or Lakoff (1987). See, however, Queixalós (2002), where the author argues that verbs with causative meaning taking two nominal arguments, which cannot govern a situation as an argument, can also be regarded as causative verbs.

[4] Maybe the semantic label 'Agent' is not exactly applicable to all examples used here - by saying 'Agent' or 'Agentive causer', I mean a causer which is an animate entity, and not an event or an abstract inanimate entity, such as reč' 'speech'. 
them can govern an embedded clause, the embedded verb being either perfective or imperfective.

The combination of the imperfective variant zastavljat' + embedded imperfective verb is found 3772 examples in the Russian National Corpus:
Mysl'- $\emptyset$
o smert-i
zastavljaj-et zadumyva-t'-sja.
thought-SG.NOM of death-SG.LOC make-PRS.3SG think.of-INF-REFL
'Thought of death makes us think.'

Imperfective variant zastavljat' + embedded perfective verb - 1029:

(5)
Eto
zastavljaj-et zaduma-t'-sja
o naš-ix
this.SG.NOM make-PRS.3SG think.of-INF-REFL about our-PL.LOC
televizionn-yx myslitelj-ax
television-PL.LOC thinker-PL.LOC
'This makes us think of our television thinkers.'

Perfective variant zastavit' + embedded perfective of the embedded verb - 2636:

(6)

$\begin{array}{lll}\text { Opyt- } \emptyset & \text { zastavi-1- } \emptyset & \text { zaduma-t'-sja } \quad \text { o } \\ \text { experience-SG.NOM make-PST-SG.M think.of-INF-REFL about }\end{array}$

vozmozhn-yx napravlenij-ax tvorčesk-ix poisk-ov possible-PL.LOC direction-PL.LOC creative-PL.GEN search-PL.GEN

'Our experience made us think of possible directions of creative process.'

Perfective variant zastavit' + embedded imperfective verb - 1838:

(7) Odnaždy dazhe zastavi-1- $\emptyset$ nervniča-t' sam-ogo Iosif-a once even make-PST-SG.M be.nervous-INF self-SG.ACC Iosif-SG.ACC Kobzon-a

Kobzon-SG.ACC

'He has once made nervous even Iosif Kobzon (a famous Russian pop singer) himself.'

The rarest cases are those in which zastavit' is in the perfective and the embedded clause contains a verb in the imperfective, and vice versa. Cases in which zastavit' and the embedded verb have the same aspectual form are much more frequent.

For pozvolit', the construction with the perfective variant of pozvolit' and imperfective embedded verb is the least frequent:

- Pf of pozvolit' + pf of the embedded verb - 7041

- Pf of pozvolit' + ipf of the embedded verb - 1961

- Ipf of pozvolit' + ipf of the embedded verb - 6518 
- Ipf of pozvolit' + pf of the embedded verb - 6645

Throughout the paper I will specifically point out the cases where I describe one or another option for the existing four variants.

With zastavit' and pozvolit', the situation is roughly the same as with sdelat'. Note, for instance, the interpretation of tense in (8):

$$
\begin{aligned}
& \text { Postupok- } \emptyset \quad \text { Rogozin-a zastavljaj-et somneva-t'-sja v } \\
& \text { action-SG.NOM Rogozin-SG.GEN make-PRS.3SG doubt-INF-REFL in } \\
& \text { naliči-i } \quad \text { u nego čest-i. } \\
& \text { presence-SG.GEN at he.GEN honour-SG.GEN } \\
& \text { 'Rogozin's action makes (us) doubt that he has any honour.' }
\end{aligned}
$$

In (8), the present tense zastavljajet does not refer to the time of the causing event (the 'action'). It rather denotes the time when the speaker doubts that Rogozin has any honour - in other words, the present tense of the causative, just as with sdelat', designates the time of the caused event. The sole difference between sdelat' and zastavit' is that examples with zastavit' all have another interpretation in which the present tense does not refer to either the time of causation or the time of the caused situation (see Section [4] below).

The same interpretation, as we have seen, is impossible with other verbs, such as xotet' or prosit', which take an infinitive construction or a subordinate clause as an argument. Note also that the same interpretation is at least improbable, if not impossible, for zastavljat' if the causer is an agent:

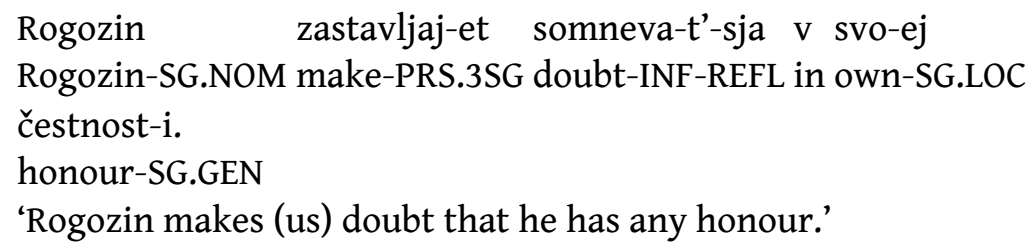

Example (9) can hardly be interpreted as 'Rogozin, by some of his actions carried out in the past, makes us doubt in his honour'. This example rather presupposes that Rogozin behaves now in such a way that we doubt in his honour. What is really important is that constructions like (8) are impossible if the caused situation does not have any duration, that is, if it is either momentary or is conceptualized as momentary. Confirm, for instance, (10), where the caused situation uezžat' 'leave' (in the imperfective variant) has a duration (the interval when many people leave the country), with (11), where the perfective variant of the same verb uexat' 'leave' is conceptualized as lacking any duration. The fact that the former is normal while the latter is semantically awkward shows that the present tense of the causative verb really refers to the caused, and not the causing, situation: 


Rezultat-y posledn-ix vybor-ov zastavljaj-ut
result-PL.NOM last-PL.GEN elections-PL.NOM make-PRS.3PL
mnog-ix uezža-t' iz stran-y.
many-PL.ACC leave.IMPF-INF from country-SG.GEN
'The results of the last elections make many people leave the country.'
*/\#Rezul'tat-y posledn-ix vybor-ov zastavljaj-ut
result-PL.NOM last-PL.GEN elections-PL.NOM make-PRS.3PL
mnog-ix uexa-t' iz stran-y.
many-PL.ACC leave.PF-INF from country-SG.GEN
'The results of the last elections make many people leave the country.

If the present tense referred to the time of the causing situation, the aspectual properties of the embedded predicate would be irrelevant to the (un)grammaticality of the whole construction. However, it is not the case: the present tense of zastavljat' 'make' refers to the time of the caused situation. This is why it is crucial for the embedded predicate to denote a situation which has some duration.

\section{[3] PAST TENSE OF THE IMPERFECTIVE MATRIX PREDICATE}

Interpretation of the past tense of imperfective verbs in causative constructions is also noteworthy. The reading is different for agentive and for eventive causers, as was the case with the present tense. With eventive causers, these forms can refer to the caused situation only:

$$
\begin{aligned}
& \text { Nabrann-ye v predydušč-em matč-e očk-i } \\
& \text { gain.PART-PL.NOM in previous-SG.LOC match-SG.LOC point-PL.NOM } \\
& \text { pozvolja-l-i im igra-t' spokojno. } \\
& \text { let-PST-PL they.DAT play-INF calmly } \\
& \text { 'The points got in the previous match allowed them to play calmly.' }
\end{aligned}
$$

Example (12) means that the points the team has got in the previous match allowed it to play calmly in the match the commentator is speaking of. In other words, the tensed form denotes the time when the team played in such way. But if the causee is agentive, this interpretation is impossible. For instance, sentences like (13) are semantically awkward:

[5] I am grateful to the anonymous reviewer for bringing my attention to the fact that sentences like Rezul'taty poslednix vyborov zastavljajut menja uexat' iz strany are acceptable at least to some extent in the 'prospective' reading ('I AM GOING to leave the country due to the result of the last elections'). Nevertheless, with interpretations like this, the sentence denotes the modal state which occurs 'between' the elections and leaving the country. Thus, here we deal with the 'modal state' interpretation (see Section [4] for details). 


??Svoj-im gol-om Ivanov pozvolja-1 im
own-SG.INS goal-SG.INS Ivanov(SG.NOM) let-PST(SG.M) they.DAT
nadeja-t'-sja' na perv-oe mest-o.
hope-INF-REFL on first-N.SG.ACC place-SG.ACC
'By his goal, Ivanov allowed them (the team) to hope for first place.'

Note that the interpretation in which the past tense refers only to the causing situation is unavailable for (13). It is impossible for this sentence to mean that thanks to the points that the team got in the previous match, the team can play carefully now; it can only mean that it could play carefully at some moment in the past.

The sentence sounds strange because the imperfective variant refers to the time when the causer (Ivanov) carries out the causing actions (scores the goal). The imperfective form designates, in cases like this, a process which has some duration - whereas the situation when the goal is scored does not have any duration. Let us compare the situation with other matrix predicates. In most cases, the imperfective past refers to the speech act or mental act itself:

$$
\begin{aligned}
& \text { Ja } \quad \mathrm{v} \text { tot moment- } \emptyset \text { xotel-I- } \emptyset \text { uexa-t'. } \\
& \text { I.NOM in that.M.SG.ACC moment-SG.ACC want-PST-SG.M leave-INS } \\
& \text { 'At this time, I wanted to leave.' }
\end{aligned}
$$

However, constructions with verbs like prosit' 'ask', trebovat' 'demand', and some other verbs of speech admit a more complicated interpretation.

$$
\begin{aligned}
& \mathrm{V} \text { pis'me otec- } \emptyset \quad \text { prosi-l- } \emptyset \text { menja priexa-t'. } \\
& \text { In letter father-SG.NOM) ask-PST-SG.M I.ACC come-INF } \\
& \text { 'In his letter, my father asked me to come.' }
\end{aligned}
$$

In (15), the past tense of the imperfective verb prosit' 'ask' refers not to the speech act itself, but to the time when the letter is received. Nevertheless, the situation is not the same as with causative verbs. What is important is that in (15), the verb form does not refer to the time when the speaker came to his father (the caused situation).

\section{[4] THE TENSE WHICH REFERS TO NOTHING}

In the cases which we have analyzed so far, the tense of the matrix (causative) predicate refers to the time when the caused situation takes place. However, in our material there are some examples where the tense does not seem to refer to the time of any subevent, either the caused or the causing one. Note that in this section, only constructions with imperfective variants of causative verbs are considered. 


Dostignut-ye izmenenij-a pozvoljaj-ut NATO v
reach.PART-PL.NOM change-PL.NOM let-PRS.3PL NATO in
dal'nejš-em otmeni-t' embargo.
future-SG.LOC cancel-INF embargo.ACC
'The attained changes allow NATO to cancel its embargo in the future.

In examples like (16), the present tense or past tense of imperfective verbs does not refer to any of the subevents. The causing event, izmenenija 'changes', has already taken place, and the caused event, otmenit' 'cancel', will probably take place in the future.

In fact, what the present tense really refers to is the 'modal' state of affairs such that the embargo can be cancelled. Note that this state is not expressed in any explicit way in (16). The same interpretation is also available for (8): it can be the case that in the future we will doubt that Rogozin has any honour. However, a more plausible interpretation is that we already have doubts; therefore, the present tense refers to the time of the caused situation. The state of affairs in (16) is the result of the changes which have been attained - and it is this resulting state which allows the embargo to be cancelled. In other words, the notion of THE RESULT OF THE CAUSING SITUATION (if there is an eventive, and not agentive causer) is crucial for the interpretation of causative constructions. ${ }^{7}$

The same is true for constructions with sdelat', as in (3). In (3) the present tense refers not only to the situation when Sainz is the record-holder, but also to the time when the resulting state (the fact of the victory) exists in the speaker's mind.

Again, constructions with causative verbs where the subject is an agent, and not an event, behave like constructions with non-causative verbs. For instance,

[6] I thank the anonymous reviewer for the important remark that the phenomenon illustrated by (16) is in fact a general one. Russian modal verbs, such as moč 'can' can have the same type of interpretation. Sentences like NATO mož-et otmeni-t' embargo (NATO can-PRS.3SG cance-INF embargo.ACC) 'NATO can cancel the embargo' also refers to the situation when NATO is in a 'modal state' when it can cancel the embargo.

This interpretation is trivial for modal verbs. By contrast, its existence in causative constructions reveals an important fact, namely, that the semantics of causative verbs also contains a 'modal state' component which can be activated in examples like (16).

[7] As an anonymous reviewer remarks, there are also cases when there is no resulting state at the reference time, but the future situation is represented by its signs before its occurrence. For instance, in (i):

'The fact that the winter should be cold (lit. 'the forthcoming frosts') made Peter buy a fur-coat.'

the future situation (morozy 'frost') is represented by some signs (for instance, the fact that frosts always occur in the winter). It is possible that constructions like (16) are sometimes possible with predicates implicating no result, and the modal state in this case follows from the causing situation in a less trivial way. However, at the moment I have too little data to discuss this matter. 
(17) can only mean that the politicians carry out some actions in the moment of speech:

$$
\begin{aligned}
& \text { Politik-i pozvoljaj-ut ljudj-am / zastavljaj-ut } \\
& \text { politician-PL.NOM let-PRS.3PL people-PL.DAT / make-PRS.3PL } \\
& \text { ljud-ej otstaiva-t' svo-e mneni-e. } \\
& \text { people-PL.ACC assert-INF own-N.SG.ACC opinion-SG.ACC } \\
& \text { 'The politicians let people assert their opinion.' }
\end{aligned}
$$

The present tense in (17) can have different interpretations (for instance, the event can take place in the moment of speech or habitually). However, it cannot be the case that the politicians have already carried out some action, thus allowing people to assert their opinions. The sentence can only mean that the politicians carry out these actions now - in some possible sense.

In the same sense, constructions with verbs like xotet' 'want', ljubit' 'like, love', or moč' 'can' presuppose that the event takes place in the moment of speech (or habitually):

$$
\begin{aligned}
& \text { Vasj-a xoč-et poj-ti v kino. } \\
& \text { Vasja-SG.NOM want-PRS.3SG go-INF in cinema.SG.ACC } \\
& \text { 'Vasja wants to go to the cinema.' }
\end{aligned}
$$

Thus, (16) should be interpreted in the following way:

(19) 'At the moment of speech, the following state of affairs exists: NATO can cancel the embargo'.

This interpretation requires some additional comment. It may seem contradictory that the same interpretation is unavailable for constructions with agentive causers, as in (17). Why is a reading like (19) impossible?

(20) 'In the moment of speech, the following state of affairs exists: people can assert their opinion'.

It seems that semantically this interpretation would be perfect (for instance, if the existing political system were to allow people to assert their opinion).

It seems that the reason why the abovementioned interpretation is infelicitous for (17) is that the resultative component that is built into the semantics of (16) is less obvious for (17). In (16), the causer is a situation (changes). As soon as the situation has taken place (the changes have been achieved), the result is obvious; it exists in the world and in the speaker's mind.

In contrast, in (17) the causer is an agent. Though it is obviously the case that the politicians carry out some actions, and that is how they let or make people assert their opinion. However, these actions are not designated in the sentence, and 
the state of affairs is not inferable from the sentence. Agents do not have any trivial results which are always or usually associated with them. In constrast, events are associated with these trivial results. For instance, the situation 'Changes took place' leads to a resultative state 'Changes have taken place'.

\section{[5] INTERPRETATION OF ADVERBIAL MODIFIERS}

Above we have seen that the tensed forms can have a special interpretation with causative verbs. They can either refer to the time of the caused event or not refer to the time of either of the two events. Another test which is used, for instance, in Ljutikova et al. (2006) to examine the event structure of the causative situation is the interpretation of temporal modifiers. Ljutikova et al. show that in Balkar, when a causative is formed from a transitive verb, temporal modifiers usually permit two interpretations: the first one when they refer to the causing event, and the second one when they refer to the caused event. For instance, modifiers like 'quickly' can mean that the causing event took place quickly ('The father quickly made (forced) the son (to) cook the soup') or that the caused event took place quickly ('The father made the son cook the soup quickly').

In contrast, in Adyghe, as shown by Letuchiy (2009) and Arkadiev \& Letuchiy (2009), the interpretation of modifiers is less free. For example, the scope of adverbials of temporal localization like njepe 'today' must include the caused situation, but not obligatorily the causing situation.

In what follows, I will show that in Russian, the situation with temporal modifiers in causative constructions is also special and is more similar to Adyghe than to Balkar.

\section{[5.1] Adverbs of temporal localization}

Let us first analyze the behavior of adverbs denoting temporal localization, such as segodnja 'today', včera 'yesterday', $v$ tri časa 'at three o'clock', and so on. The causative constructions can be divided with respect to this criterion (as well as other criteria mentioned above) into agentive (with agentive causers) and eventive (with eventive causers). If the causer is an agent, adverbials of temporal localization refer either to both subevents of causative verbs, such as pozvolit' 'allow, let', zastavit' 'make', or only to the causing event:

$$
\begin{aligned}
& \text { Včera ej pozvoli-l-i nenadolgo vsta-t' s postel-i. } \\
& \text { yesterday she.DAT let-PST-PL for.short stand.up-INF from bed-SG.GEN } \\
& \text { 'Yesterday she was allowed to get out of her bed for a short time.' }
\end{aligned}
$$

At first glance, the adverbial včera 'yesterday' in (21), seems to refer both to the causing event (the time when they (the doctors) allowed the patient to stand up) and the caused event (the time when the patient stood up). It may be the case 
that the caused event has not taken place at all (the patient has not stood up), but if it took place, (21) means that the patient stood up yesterday, and not at any other time. However, in reality, the interpretation that she got out of the bed YESTERDAY is a cancelable implicature; for instance, it can be cancelled if there is another adverbial referring to the caused event. Therefore, the adverbial včera 'yesterday' really refers only to the causing situation.

The situation is different with eventive causers. Adverbials of the same type can refer not only to the whole causative situation, but also to the caused subevent: [Context: The turnover of the Russian market does not decrease]
Včera et-o pozvoli-l-o Nabiullin-oj doloži-t' yesterday it-SG.NOM let-PST-SG.N Nabiullina-SG.GEN report-INF Putin-u, čto ekonomik-a razvivaje-t-sja stabil'no. Putin-SG.DAT that economics-SG.NOM develop-INF-REFL stably 'This let Nabiullina report to Putin yesterday that [Russian] economics develops stably.'

In (22), Nabiullina reported the situation to Putin once, and her report took place 'yesterday', so the caused event is what the adverbial včera refers to. By contrast, the situation denoted by eto 'it' (the situation on the market) takes place permanently. It can hardly be said that this situation took place yesterday.

Note that normally adverbials situated before the main predicate cannot be interpreted with respect to the embedded verb: cf. (23), with an agentive causer, and (24), with a non-causative predicate:

Včera Putin svo-imi dejstvij-ami pozvoli-l

Yesterday Putin(SG.NOM) own-PL.INS action-PL.INS let-PST(SG.M)

izmeni-t' situacij-u $\quad \mathrm{v}$ gosudarstv-e.

change-INF situation-SG.ACC in state-SG.LOC

'Yesterday, Putin let (made possible that) the situation in the state change.'

(24) Včera general prikaza-l soldat-am

yesterday general(SG.NOM) order-PST(SG.M) soldier-PL.DAT

marširova-t'

march-INF

'Yesterday, the general ordered the soldiers to march.'

In (23), with an agentive causer, the adverbial včera 'yesterday' refers to Putin's actions, and not to the time when the situation in the state changed. In the same way, (24) means that the general's order took place yesterday (note that it is not necessary that the soldiers marched yesterday or today). Moreover, (24) does not presuppose that the soldiers marched at all. 


\section{[5.2] Frequency adverbs}

The situation with adverbs of frequency, such as často 'often' is roughly the same. In constructions with eventive causers, it is possible that a frequency adverb situated before the causative verb refers only to the caused situation. The causing situation (obrazovanie 'education' in (25) and nacionalnost' 'nationality' in (26)) has taken place once and is not repeated. In contrast, when the causer is an agent, as in (27), the frequency adverb can only refer to the event as a whole meaning that the causing event is always repeated:

(25) Mo-e obrazovani-e často pozvoljaj-et mne ob"ektivno my-N.SG.NOM education-SG.NOM often let-PRS.3SG I.DAT objectively oceniva-t' situacij-u.

estimate-INF situation-SG.ACC

'My education often allows me to estimate the situation objectively.'

(26) Ego nacional'nost' vsegda zastavljaj-et ego by-t' na

his nationality-SG.NOM always make-PRS.3SG he.ACC be-INF on storon-e russk-ix.

side-SG.LOC Russian-PL.GEN

'His nationality makes him be on the Russians' side.'
Pap-a
vsegda zastavljaj-et menja my-t'
po
father-SG.NOM always make-PRS.3SG I.ACC wash-INF in
večer-am posud-u.
evening-PL.DAT dishes-SG.ACC
'My father always makes me wash dishes in the evening.'

The same is true for non-causative predicates taking an embedded infinitive argument. In constructions with these verbs, a frequency adverb always denotes the repeatedness of the causing situation:

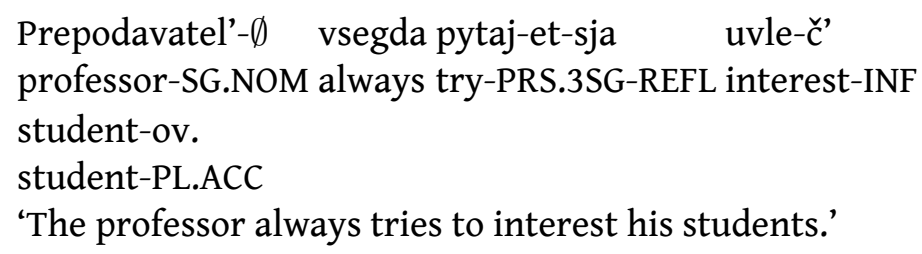

It may seem that the case of frequency adverbs is not accounted for by the notion of result that we used to describe the semantics of constructions like (16) and (17). However, this is not the case.

Indeed, the very fact that NPs like obrazovanie 'education' can denote the result of education does not account for the interpretation of frequency adverbials like často. But the matter becomes clearer if we recall another property of results: 
a result does not cease to exist except in some very special cases. Therefore, it is not strange that, for instance, the result of the education mentioned in (25) can be evident throughout the whole life of the speaker. The case of (26) is even clearer: individual-level properties, like nacional'nost' 'nationality', do not change throughout the whole life of a person.

Yet another fact is not accounted for: why is the interpretation in (25) impossible for the agentive causer in (27)? The agent (papa 'father') also exists for a long time, but the given interpretation cannot be reached: adverbials like často in constructions with agentive causers are applicable only if the situation expressed in the matrix clause with the causative verb has taken place many times.

The reason seems to be that agentive causers cannot be the reason of the caused situation by themselves. According to Nedjalkov \& Sil'nickij (1968) and Pylkkänen (2002), the causative construction presupposes that a new subevent is added to the initial situation, and it is the new situation which causes the emergence of the caused situation ${ }^{8}$. In other words, each sentence like John made Mary go out really means something like 'John's actions made Mary go out'. Thus, for (27), some events the father takes part in should be added to the semantics of the situation. A default event is not a state, but rather a process or a momentary event - thus, it is not surprising that these types of events have some restricted duration. This is why the default (and the only natural) interpretation for (27) is that the father makes me wash the dishes by different actions in different periods of time - and the adverb vsegda 'always' refers both to the causing and to the caused situations.

\section{[6] PARALLELS IN OTHER DOMAINS}

The situation in the domain of Russian causatives, where aspectual properties and interpretation of temporal forms depend crucially on the agentivity of the subject (external argument), is by no means unique in Russian grammar. Paducheva (2004) shows that many verbs (for instance, verbs of spatial localization and motion) show the same type of shift depending on the agentivity of the subject:

Ivan- $\emptyset$ zagoraživa-1- $\emptyset$ proxod- $\emptyset$ mešk-ami. Ivan-NOM block-PST-SG.M way-SG.ACC sack-PL.INS 'Ivan blocked the way with the sacks.'
Mešk-i zagoraživaj-ut proxod- $\emptyset$.
sack-PL.NOM block-PRS.3PL way-SG.ACC
'The sacks block the way.'

[8] Here we leave aside the an alternative hypothesis that for causativization the addition of a new participant (causer), and not of a new subevent, to the structure of the event, is relevant. This point of view is represented, among others, by Shibatani (1976). 
In (29), where the subject is agentive, the dynamic interpretation occurs: the sentence denotes that Ivan was blocking the way with sacks, changing their localization. By contrast, in (30), the interpretation is stative. In this section, the state of affairs when the sacks are on the way is referred to. This is rather close to the contrast observed in (25), (26) vs. (27).

However, there are some differences between meaning shifts observed by $\mathrm{Pa}-$ dučeva and those occurring with the causative verbs. The main difference is that verbs like zagoraživat' 'block' do not govern sentential arguments.

From this difference, others, less obvious, follow. When verbs like zagoraživat' 'block' have the stative reading the tense (e.g. the present tense in (30)) refers to the moment when the change of state has already taken place, and the resulting state is taking place in the moment of speech, following the change of state. In contrast, in examples like (16), the present tense does not mean that the change of state zastavit' 'make' has already taken place. On the contrary, the change of state can take place, and the state which is taking place in the moment of speech precedes the change of state.

It is not obvious whether these two cases can be reduced to one. I think that there are common features. The main of them is that the eventive subjects of $z a-$ stavljat', as in (12) and (16) and the non-agentive causers of zagoraživat', as in (30), both impose a resultative interpretation. However, the result is related differently to the semantics of the sentence. In (12) and (16), the semantics contains the resultative component, but this component emerges because the situation has an eventive causee. In contrast, the semantics of localization verbs like zagoraživat' contain the result of the process of blocking. In other words, in the stative reading the verb denotes the result of the situation designated by the eventive reading.

[7] RUSSIAN CAUSATIVES AND RAMCHAND'S STRUCTURE OF CAUSATIVES

As Franks (1990), Franks \& Hornstein (1992), Franks (1995), Babby \& Franks (1998) and others show, Russian constructions with infinitive-taking verbs are biclausal, though they may semantically designate one complex event.

Note that the very class of biclausal constructions is not homogenous. Consider, for instance, the opposition noted by Minor (2007, unpublished). Minor notes that nibud'-pronouns are possible in constructions with infinitive complements, thus proving them to be biclausal (see Minor's work for detailed argumentation):

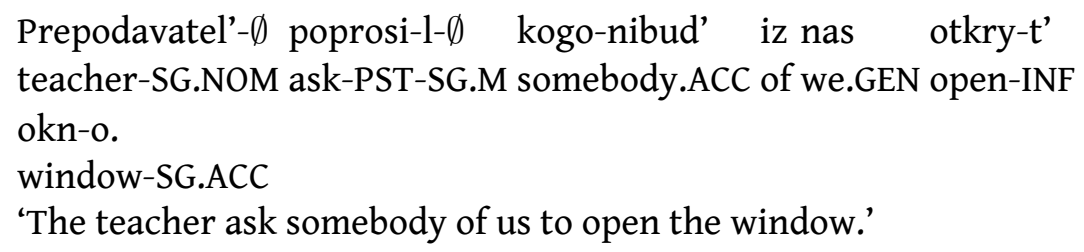


Sentence (31) is biclausal, while (32) is monoclausal. However, this criterion does not seems to work with the causative verbs under analysis in the same way as with speech act verbs like poprosit' 'ask', because sentences like (33) are unacceptable:

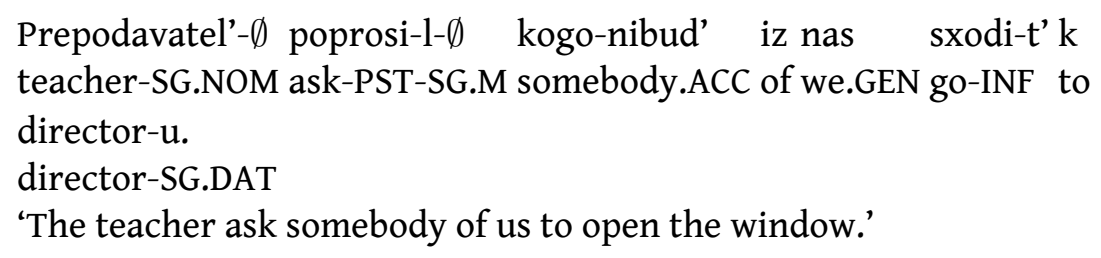

This shows one more time that the causative constructions with zastavit' and pozvolit' are in many respects closer to monoclausal causative constructions than constructions with speech acts, though this issue is outside the scope of the present paper.

In formal literature, mainly monoclausal causative constructions have been addressed. Among the recent approaches, Ramchand's one 2008 seems to be the most plausible to a wide set of typological data. Ramchand (2008) proposes the following syntactic representation of the event structure of causatives. Her structure includes a $v P$ projection corresponding to the causation, while the structure of the initial verb depends on its own properties. For instance, in (29) the event structure of the Japanese causative hashir-ase-ru [run+ CAUS] is represented. The base verb hashiru 'run' is unergative and has both a $v P$ and a VP. This structure was used by Ljutikova et al. (2006) and Arkadiev \& Letuchiy (2009) to test the properties of causative constructions.

This schema can be applied to monoclausal causative constructions. However, it turns out that biclausal constructions have additional interpretations. If we tried to apply Ramchand's schema to Russian biclausal causative constructions addressed in this paper, we would notice that this schema does not take into account the interpretations of tensed forms and temporal modifiers of the type discussed here, in particular the eventive causers, especially of the type in (16), in which the present tense refers neither to the causing event nor to the caused event, but to the state of affairs existing after the causing event has already taken place, and the caused event only has to take place. This state of affairs is the result of the caused situation. 
(34)

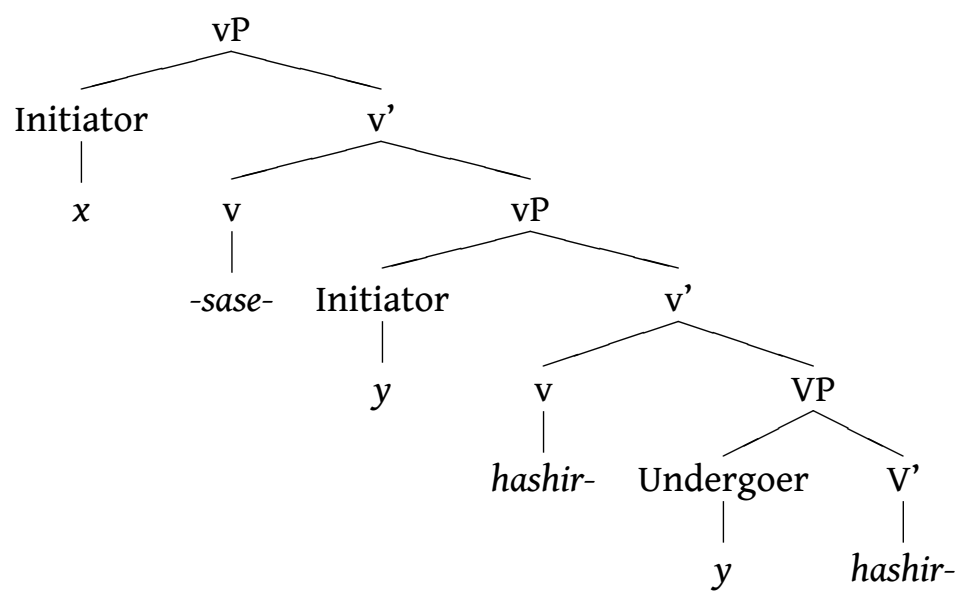

Thus, in order to capture the Russian data presented above and, perhaps, biclausal causative constructions in other languages, we need to introduce this state somewhere in the event structure of causative situations. The precise formal implementation of this requires further study. Note that the fact that the construction is biclausal does not allow us to avoid the question how the state of affairs mentioned above can be represented: if we represent the construction in (16) as including two different clauses with two different verbs, this does not allow us to overlook the fact that the verb pozvoljat' is interpreted statively in this sentence.

The properties of constructions with an eventive causer shed some light on another problem, namely, the set of participants in the causative construction like (16), More precisely, what is the causer of this type of construction? At first glance, it may seem that the causer is izmenenija 'changes' and that this semantic structure is parallel to that of (17) where the causer is politiki 'politicians'. Yet, the two constructions are not entirely parallel.

In examples like (9) and (17) that have an agentive causer, the causer is really the agentive participant that is designated by the subject NP. In examples like (8) and (25), the situation is more complicated. As I have said, the causer is really not the event itself but rather the result of this event. These sentences can be rephrased as 'The fact that some changes took place...' or 'The fact that I have education'. The event in the narrow sense (changes, education) is a part of another event (changes and their results, education and its result).

The data which I have analyzed in the present paper require that Ramchand's structure should be supplemented in some way with a result component. It should allow us to interpret structures in which not the causing event itself, but rather its result, is what is responsible for the emergence of the caused situation. 


\section{[8] CONCLUSIONS}

In the present paper I analyzed the interpretation of tense and aspect forms, as well as some groups of adverbial modifiers, with causative verbs zastavit' 'make', pozvolit' 'let, allow', and sdelat' 'make' in Russian.

Though the exact formal mechanism which should be used to account for the tendencies observed can be different, it is evident that there are some crucial distinctions between the predicates under analysis, depending on whether their syntactic subject is an agent or an event. Note that the contrast between sentences like (8) and (9), which mainly differ in whether the syntactic subject is an agent or an event, shows that the semantic representation proposed, for instance, by Nedjalkov \& Sil'nickij (1968) - that presupposes that any causative construction denotes a semantic relation between two subevents (the causing one and the caused one) - is not sufficient for the description of all causative constructions. In many cases, the surface expression of the participants is crucial for the causative construction.

The striking feature of the causative constructions with eventive subjects is that the tensed forms and temporal adverbs in these constructions do not obligatorily refer to the causing situation. The tensed forms and adverbials sometimes refer only to the caused situation.

I assume that it is the nature of events vs. participants that is responsible for these distinctions. Each dynamic event is associated with some result. I have shown that in some cases what the tense of the causative verb and temporal adverbials refer to is the result of the causing event, and not the causing event in the narrow sense.

The overall result is that causative constructions with an agentive causee behave like constructions with an embedded infinitive. In contrast, constructions where the causer is an event behave in another way that is similar, in some respects, to the behaviour of grammatical causatives in some other languages, such as Adyghe (see Arkadiev \& Letuchiy 2009). This seems to be a controversial result, since Lakoff (1987), for instance, considers constructions with an agentive causee to constitute the prototype of causative constructions. However, this result is absolutely natural for a language without grammatical marking of causation, such as Russian. In constructions with agentive causers, causative verbs not only denote the causation, but also bear some additional semantic components (for instance, zastavit' presupposes that the causer imposes his or her will on the causee by force). In constrast, when the causer is an event, these components become weaker or even vanish from the semantics of the verb. 
ABBREVIATIONS

ACC - accusative case, DAT - dative case, F - feminine (gender), GEN - genitive case, INF - infinitive, INS - instrumental case, IPF - imperfective aspect, $\mathrm{N}$ - neutral (gender), M - masculine (gender), NOM - nominative case, PF - perfective aspect, PL - plural, PRS - present tense, PST - past tense, REFL - reflexive suffix, SG - singular.

\section{REFERENCES}

Arkadiev, Peter \& Alexander Letuchiy. 2009. The syntax and semantics of event structure and Adyghe causatives. Ms. Available from: http://ling. auf . net/ lingBuzz/000811.

Babby, Leonard \& Steven Franks. 1998. The Syntax of Adverbial Participles in Russian Revisited. The Slavic and East European Journal 42(3). 483-516.

Boguslavskaya, Olga Yu. 2005. Kauzativnye glagoly v russkom jazyke [Causative verbs in Russian]. Handout of talk presented in the Seminar for Theoretical Semantics. Moscow.

Bybee, Joan, Revere Perkins \& William Pagliuca. 1993. The Evolution of Grammar: Tense, Aspect and Modality in the Languages of the World. Chicago: University of Chicage Press.

Comrie, Bernard. 1976. The syntax of causative constructions: Cross-language similarities and divergences. In M. Shibatani (ed.), The Grammar of Causative Constructions, vol. 6 Syntax and Semantics, 261-312. New York: Academic Press.

Franks, Steven. 1990. Case, Configuration and Argumenthood: Reflections on the Second Dative. Russian Linguistics 14(3). 231-254.

Franks, Steven. 1995. Parameters of Slavic morphosyntax. Oxford: Oxford University Press.

Franks, Steven \& Norbert Hornstein. 1992. Secondary predication in Russian and proper government of PRO. In R. Larson, S. Iatridou, U. Lahiri \& J. Higginbotham (eds.), Control and Grammar, 1-50. Dordrecht: Kluwer.

Ivanov, Mikhail \& Maria Yu. Babicheva. 2010. Aspectual composition in causatives. In M. Duguine, S. Huidobro \& N. Madariaga (eds.), Argument Structure and Syntactic Relations, 13-34. Amsterdam \& Philadelphia: John Benjamins.

Lakoff, George. 1987. Women, Fire, and Dangerous Things. Chicago: The University of Chicago Press. 
Lehmann, Christian. 1982. Thoughts on Grammaticalization. A programmatic Sketch, vol. I (Arbeiten des Kölner Universalien-Projekts 48) Köln.

Letuchiy, Alexander. 2009. Kauzativ, dekauzativ i labil'nost' [Causative, anticausative and lability]. In Y.G. Testelets, P.M. Arkadiev, A.B. Letuchiy \& N.R. Sumbatova (eds.), Aspekty polisintetizma: očerki po grammatike adygejskogo jazyka [Aspects of polysynthesis: grammar of the Adyghe language], Moscow: Russian State University for Humanities.

Ljutikova, Ekaterina A., Sergei G. Tatevosov, Mikhail Yu. Ivanov, Anna G. Pazel'skaya \& Andrei B. Šluiskij. 2006. Struktura sobytija i semantika glagola $v$ karačaevo-balkarskom jazyke [Structure of event and semantics of verb in the Karachay-Balkar language]. Moscow: Institute for World Literatures.

Minor, Sergei. unpublished. Tipologija pod"jema argumenta v konstrukcijax s sentencial'nymi aktantami. Ms.

Minor, Sergei A. 2007. Ob"ektnyj kontrol' i pod"jem argumenta v russkom jazyke. In F.I. Dudchuk, N.V. Ivlieva \& A.V. Podobriaev (eds.), Struktury $i$ interpretacii. Raboty molodyx issledovatelei po teoretičeskoj i prikladnoj lingvistike, 104-126. Moscow: MSU.

Nedjalkov, Vladimir P. \& Georgi G. Sil'nickij. 1968. Tipologija morfologičeskogo i leksičeskogo kauzativov [Typology of morphological and lexical causatives]. In A.A. Xolodovič (ed.), Tipologija kauzativnyx konstrukcij [Typology of causative constructions], Leningrad: Nauka.

Nichols, Johanna, David A. Peterson \& Jonathan Barnes. 2004. Transitivizing and detransitivizing languages. Linguistic Typology 8(2). 249-311.

Paducheva, Elena V. 2001. Kauzativnyj glagol i dekauzativ v russkom jazyke [Causative verb and anticausative in Russian]. Russkij jazyk $v$ naučnom osveščenii 1. 52-79.

Paducheva, Elena V. 2004. Dinamičeskie modeli v semantike leksiki [Dynamic models in the lexical semantics]. Moscow: Jazyki slavjanskoj kul'tury.

Pylkkänen, Liina. 2002. Introducing arguments. MIT Press.

Queixalós, Francesc. 2002. The notion of transfer in Sikuani causatives. In M. Shibatani (ed.), The Grammar of Causation and Interpersonal Manipulation, 319-340. Amsterdam \& Philadelphia: John Bejamins.

Ramchand, Gillian. 2008. Verb Meaning and the Lexicon: A First Phase Syntax. Cambridge: CUP. 
Shibatani, Masayoshi. 1976. The Grammar of Causative Constructions. Syntax and Semantics 6.

Shibatani, Masayoshi \& Prashant Pardeshi. 2002. The causative continuum. In M. Shibatani (ed.), The Grammar of Causation and Interpersonal Manipulation, 85-126. Amsterdam \& Philadelphia: John Benjamins.

AUTHOR CONTACT INFORMATION

Alexander Letuchiy

National Research University Higher School of Economics

Dekabristov str., house 38, apartment 134

127273 Moscow

Russia

alexander.letuchiy@gmail.com 